\title{
Response of Soil Microbial Community to Organic and Conventional Taiwanese Tea Farming
}

\author{
Yu-Chieh Piao (Stacy) ${ }^{1}$, Ping-Chun Lucy Hou ${ }^{1}$, Song Bin Chang ${ }^{1}$, Yosef Steinberger ${ }^{2 *}$ \\ ${ }^{1}$ Department of Life Sciences, National Cheng Kung University, Tainan, Taiwan \\ ${ }^{2}$ The Mina \& Everard Goodman Faculty of Life Sciences, Bar-Ilan University, Ramat Gan 5290002, Israel \\ Email: yosef.steinberger@biu.ac.il \\ This paper is dedicated to the loving memory of our supervisor and friend, Prof. PC.L. Hou
}

\begin{abstract}
The organic certification process is financially impossible for many tea-farm producers. Differences in soil physicochemical properties, microbial physiological variables, and community structure were investigated in organic and conventional agroecosystems in Nantou County, central Taiwan. Soil samples were collected monthly in 2011 from two study sites: below tea shrub canopies (TI) and between tea shrubs (TII). Abiotic and biotic soil parameters were analyzed using two-way ANOVA to determine the impact of farming type and sampling location. Microbial-community structure and functional diversity were determined based on substrate-induced respiration, indicating the metabolic potential of the microbial community. The results indicate that organic farming can reduce the metabolic quotient $\left(\mathrm{qCO}_{2}\right)$ and basal respiration, and increase microbial-community functional diversity and catabolic ability, especially with amino acids and carbohydrates. The addition of fertilizers will decrease the metabolic function of bacterial communities. We attribute these results to the continuous supply of fresh organic matter that maintains long-term carbon bioavailability, improving nutrient supply to yield production.
\end{abstract}

Keywords: Carbon availability, conventional farming, organic farming, soil microbial community, tea farming.

\section{Introduction}

One of the most common practices in organic farming in an agricultural system is to leave the organic debris in the field in order to enhance biological activity and diversity, to promote soil fertility during the decomposition process, and in addition, in order to decrease weed growth, thus reducing the area of weeds to be tidied. In the decomposition process, soil microorganisms play a critical role in ecosystem functions, i.e., soil structure [1], soil quality [2], pest control [2], material decomposition [3], the nutrient cycle [4], and in plant-community composition [5,6]. Enhancing the understanding of a soil microbialmediated process is, therefore, essential for achieving sustainable agriculture.

Ecosystem resilience may decrease when microbial species diversity decreases [7]. Species diversity and functional diversity are correlated, but functional diversity has a greater impact on ecosystem processes than species diversity [8]. Thus, microbial functional diversity is a good indicator of disturbances and for predicting soil function, even though the functional redundance of the ecosystem is high or a disturbance has just taken place [9-12].

Recently, researchers have become interested in comparing the soil processes of organic and conventional farming systems. The general setting of organic-farming study means operation without herbicides, insecticides, and mineral fertilizer, but with animal manure or compost [2, 9, 13-17]. However, it is unusual that conventional farming is compared with organic farming, which abandons all artificial managements except harvesting.

Traditional culture-based techniques for a microbial community cover only $1 \%$ of the soil bacterial species of the total bacterial populations and $17 \%$ of fungal species [10, 18-20], not to mention the taxonomic disputes and unknown functions of these species. Recently, several methods have been developed to assay structure and potential function of a microbial community. Such methods include polymerase chain reaction - denaturing gradient gel electrophoresis (PCR-DGGE), phospholipid fatty 
acids (PLFA), MicroResp ${ }^{\mathrm{TM}}$, and BIOLOG [21-24]. MicroResp ${ }^{\mathrm{TM}}[25]$ is an alternative method for constructing a community-level physiological profile (CLPP) and the functional diversity of a microbial community. Its advantages include the use of whole-soil samples rather than a soil extract (elimination of extraction bias), rapid response based on substrate-induced respiration (SIR), and utility in a wide range of soils with better discrimination $[10,12,18,26]$. MicroResp ${ }^{T M}$ reflects the activity of fastgrowing, aerobic and heterotrophic microbes and those organisms capable of utilizing available carbon sources [10, 18], which represent the availability of food resources in the soil, such as plant root exudates [27-29].

The purpose of this study was to explore how agricultural managements (organic and conventional) influence the physicochemical conditions, microbial community, and metabolic function of the soil. We also investigated the relationship between physicochemical properties and physiological variables. Soil samples were, therefore, collected from beneath canopies and between tea shrubs from a conventional farm $(\mathrm{CA})$ and an organic farm $(\mathrm{OA})$.

We hypothesized that organic farming will improve soil function within natural ecosystem boundaries by increasing microbial functional diversity and soil microbial-community activity compared with conventional farming. At both sampling sites the soil samples beneath and between tea shrubs will similarly be affected by tea plant residues.

\section{$2 \quad$ Materials and Methods}

\section{$2.1 \quad$ Study Site}

The study site was located in the Mingjian agricultural area, western Nantou County in central Taiwan.

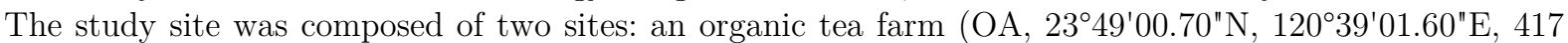
$\mathrm{m}$ above sea level) and a conventional tea farm ( CA, 23 $51^{\prime} 34.00^{\prime \prime} \mathrm{N}, 120^{\circ} 38^{\prime} 13.80^{\prime \prime} \mathrm{E}, 390 \mathrm{~m}$ above sea level). Both farms were 1500 square meters in size. The mean annual temperature at the study site was $22.2^{\circ} \mathrm{C}$, and the mean multiannual precipitation (over15 year period) was $1980 \mathrm{~mm}$.

The soils at both study sites were red ultisols [30]. The basic physicochemical properties of the soil are described in Table 1.

The tea-shrub species in both farms are Camellia sinensis, planted in rows with a width of $1.5 \mathrm{~m}$. The weeds of the organic tea farm flourish all the year round and are dominated by Oplismenus hirtellus, Paspalum conjugatum, Cyrtococcum patens, Peristrophe roxburghiana, and Ageratum houstonianum.

\section{$2.2 \quad$ Management}

Management at the conventional tea-farm study site included shrub pruning in February and the harvest period starting in April and ending in November. A total of four to five harvests were conducted, with intervals of 45 to 50 days between each harvest in order to allow the plants to re-grow.

At the organic farm, there was no artificial management, i.e., watering, plowing, or application of insecticides or herbicides in the past 13 years, except for the application of slow-release organic fertilizer in early January. At the conventional farm, mineral fertilizers ( $N: P: K=20: 5: 1$ ), or insecticides were applied following the pruning and harvest periods. Irrigation during the year was a function of precipitation abundance and dispersion. Rice bran and peanut shell amendments were applied between the tea-farm rows at the conventional farm in order to prevent evaporation from the soil and to improve soil organic matter.

\subsection{Soil Sampling and Physicochemical Properties}

Two sets of soil samples were collected from each study site on the same day before harvesting: one below the shrub canopy $(\mathrm{n}=5)(\mathrm{TI})$ and the other between the tea shrubs (open space) $(\mathrm{n}=5)(\mathrm{TII})$. The soil samples were collected from the upper soil layer of 0-10 cm depth with a soil corer (diameter $=5.5$ $\mathrm{cm}$ ). Four soil subsamples were pooled together to represent one soil sample as one replicate. These soil samples were kept in an insulated ice box to prevent overheating, and transported to the laboratory, 
where they were kept at $4^{\circ} \mathrm{C}$ for a maximal 48 hours, awaiting chemical and biological analysis after being sieved ( $\leqq 2 \mathrm{~mm})$ to remove plant roots and debris.

Soil moisture content (SM) was determined gravimetrically by drying the soil at $105^{\circ} \mathrm{C}$ for $24 \mathrm{~h}[31$, 32].

Water-holding capacity (WHC) was determined by applying tap water to $40 \mathrm{~g}$ dry soil samples from each treatment in a bottom-perforated vessel. The WHC was inferred from the amount of residual water remaining following the draining of gravitational water [31].

$\mathrm{pH}$ was determined using a combined $\mathrm{pH}$ electrode in the filtered supernatant of a mixture of $20 \mathrm{~g}$ fresh soil and $40 \mathrm{ml}$ distilled $\mathrm{H}_{2} \mathrm{O}$ following shaking for 10 min at $140 \mathrm{rpm}$ [33].

Organic matter $(\mathrm{OM})$ was determined by the loss-on-ignition method, a modification of a method described by Ben-Dor and Banin [34]. An amount of three grams oven-dried soil was placed in a ceramic crucible, which was then heated at $400^{\circ} \mathrm{C}$ for $4 \mathrm{~h}$. The value of $\mathrm{OM}$ was calculated as the difference between the initial and final sample weights divided by the initial sample weight expressed as percent $[35,36]$.

Total soil nitrogen (TN) was determined by using the Kjeldahl method [37]. One gram of oven-dried soil was introduced into a flask and mixed with $4 \mathrm{ml}$ concentrated $\mathrm{H}_{2} \mathrm{SO}_{4}(98 \%)$ and at least $0.27 \mathrm{~g}$ catalyst mixture $\left(\mathrm{K}_{2} \mathrm{SO}_{4}: \mathrm{CuSO}_{4} \cdot 5 \mathrm{H}_{2} 0: \mathrm{Se}=50: 10: 1\right)$. It was heated until digestion was completed. Ammonium was measured using alkaline distillation and titration. Total soluble nitrogen (TSN) was determined using $20 \mathrm{~g}$ fresh soil mixed with $50 \mathrm{ml} 2 \mathrm{M} \mathrm{KCl}$, as described by Keeney and Nelson [38]. The mixture was shaken for $1 \mathrm{~h}$ and the filtered supernatant was collected, followed by stirring for $30 \mathrm{~min}$. The filtrate was measured using an autoanalyzer for total nitrogen [37].

\subsection{Physiological Variables and a Microbial Community}

Soil subsamples from each replicate were adjusted to $40 \%$ soil moisture content of WHC and preincubated in the dark at $25^{\circ} \mathrm{C}$ for 2 days $(48 \mathrm{~h})$ before catabolic assay. Pre-incubated soil samples were added to the deep-well microplate after loading carbon substrates in the relevant wells. The microplate was attached to a colorimetric detection plate via a perforated seal and incubated at $25^{\circ} \mathrm{C}$ for $6 \mathrm{~h}$. The detection plates were read by inserting them in a plate reader spectrophotometer at $570 \mathrm{~nm}$ before sealing the deep-well plates (Time 0) and after $6 \mathrm{~h}$ incubation (Time 6). The absorbance of each well was calculated based on the $\mathrm{CO}_{2}$ concentration at time zero and the level of $\mathrm{CO}_{2}$ after $6 \mathrm{~h}$ [25].

$\mathrm{CO}_{2}$ evolution and microbial biomass were determined using the MicroResp ${ }^{\mathrm{TM}}$ system [25]. Water was added to soil samples in a deep-well microplate in order to determine basal respiration (BR), and glucose was added to quantify microbial biomass (MB) based on the substrate-induced respiration method (SIR) [39].

Metabolic quotient for $\mathrm{CO}_{2}\left(\mathrm{qCO}_{2}\right)$ is a specific activity parameter for estimating the effects of environmental conditions on soil microbial biomass. It was calculated according to the equation $\mathrm{qCO}_{2}=$ basal respiration $(\mathrm{BR}) /$ microbial biomass $(\mathrm{MB})$

$[40,41]$.

Soil microbial substrate utilization functional diversity $\left(\mathrm{H}^{\prime}\right)$ was determined by the MicroRespTM system [25], consisting of a deep-well microplate $(1.2 \mathrm{ml})$ filled with soil and aqueous carbon substrates, a perforated seal, and a colorimetric detection plate for absorbing $\mathrm{CO}_{2}$. The respiratory response to the following fifteen carbon substrates (Table 2) was tested at $30 \mathrm{mg} / \mathrm{ml}$ soil water: five carbohydrates (arabinose, fructose, galactose, glucose, and trehalose), six amino acids (alanine, arginine, cysteine $\mathrm{HCl}$, $\checkmark$-amino butyric acid, lysine, and N-acetyl glucosamine), three carboxylic acids (citric acid, malic acid, and oxalic acid), and one aromatic carboxylic acid (protocatechuic acid).

Microbial functional diversity $\left(\mathrm{H}^{\prime}\right)$ was determined using the Shannon-Weaver index $\left(\mathrm{H}^{\prime}\right): \mathrm{H}^{\prime}=-\Sigma \mathrm{Pi}$ $(\ln \mathrm{Pi})$, where $\mathrm{Pi}$ is the ratio of the activity of a particular substrate and the sum of the activities of all substrates [42].

The colorimetric detection plate, as a $\mathrm{CO}_{2}$ trap, was prepared by loading microplate wells with $150 \mu \mathrm{l}$ Nobel agar (1\%)-based gel intermixed with cresol red $(12.5 \mu \mathrm{g} / \mathrm{ml})$, potassium chloride $(150 \mathrm{mM})$, and sodium bicarbonate $(2.5 \mathrm{mM})$ [25]. All detection plates were stored in a sealed bag with soda lime for $\mathrm{CO}_{2}$ absorption and wet tissue to avoid desiccation of the gel. 


\subsection{Data Analyses}

All soil physicochemical properties and physiological variables were analyzed $(\mathrm{n}=5)$ using two-way ANOVA with two factors: farming type (CA and OA) and sampling position (TI and TII). A Tukey's comparison of all means of treatments (CAI, CAII, OAI, and OAII was performed for all variables, if a significant effect of factors was detected [28]. The Pearson correlation coefficient was used to test the correlation between variables (SM, pH, TN, TSN, OM, WHC, MB, BR, qCO2, and H'). The abovementioned statistical analyses were conducted using MINITAB 14 (Minitab Inc., Phoenix, AZ).

The metabolic profiles of SIR, the $\mathrm{CO}_{2}$ concentration response of the soil microbial community under the stress of 15 different substrates, were $\log (\mathrm{x}+1)$-transformed, and a resemblance matrix was created on normalized data using Euclidean distances. Ordination by non-metric multidimensional scaling (MDS) was used to show the pattern of functional profiles. Similarity-percentage (SIMPER) analysis was used to calculate the contribution percentage of individual substrates to grouping soils by functionality were performed using PRIMER 5 [26].

\section{$3 \quad$ Results}

The total annual rainfall during the 2011 study period was $1210 \mathrm{~mm}$ (Fig. 1), which was $44 \%$ less than the mean precipitation of the previous four years. The rainy days were unevenly distributed throughout the year. Eighty-five percent of the precipitation occurred in the summer season (May to November). Almost $30 \%$ of the rain fell in July, which was the highest amount for any month throughout the year.

\subsection{Soil Physicochemical Properties}

Rainfall distribution and its abundance were reflected in the pattern of soil moisture content on a temporal basis. The soil moisture level reached a mean value of $58.9 \%$ and a minimal value of $19.9 \%$ was recorded in May (Fig. 2). Soil moisture was significantly affected $(\mathrm{p}<0.001)$ by farming type and location (Tables 1, 3). Moreover, there were no significant differences in soil moisture between CA-TI, OA-TI, and OA-TII, where the soil moisture at CA-TII (51.27 $\pm 0.96 \%)$ was twice as much as the others $(\mathrm{p}<0.001)$. Furthermore, soil moisture had a positive correlation with total $\mathrm{N}$, total soluble $\mathrm{N}$, organic matter, and water-holding capacity (Table 4).

Farming type and sampling location significantly $(\mathrm{p}<0.001)$ affected $\mathrm{pH}$ values (Table 3). Conventional farming soil exhibited lower $\mathrm{pH}$ both under the canopy and between the shrubs. The $\mathrm{pH}$ was lowest in the CA-TII, reaching a value of $3.21 \pm 0.03$, while no significant difference was found between OA-TI and OA-TII (Fig. 2). A significant correlation was found between $\mathrm{pH}$ and total nitrogen, organic matter, and water-holding capacity of the soil (Table 4).

Farming type and sampling location had significant effects $(\mathrm{p}<0.001)$ on the soil nitrogen concentration (Table 3). The highest total N $\left(0.86 \pm 0.02 \mathrm{~g}^{*} \mathrm{~kg}-1\right)$ and total soluble $\mathrm{N}(211.00 \pm 16.6 \mu \mathrm{g}$ soil $\mathrm{g}^{-1}$ ) were found (Fig. 2) between the shrubs at the conventional farm, where they reached values that were four and ten times higher compared to the others, respectively (Table 2). No significant difference was found in TSN between CA-TI, OA-TI, and OA-TII, and TN at OA-TI was significantly lower than at CA-TI and OA-TII. The soil nitrogen concentration was positively correlated with organic matter and water-holding capacity of the soil (Table 4).

Organic matter and water-holding capacity reflected the same pattern in relation to both farming type and sampling location (Fig. 2; Table 3). The organic matter and water-holding capacity between the shrubs (TII) were much higher than under the canopy (TI) at a conventional farm, but were not significantly different at the organic farm (Table 1). A strong positive correlation was found between soil moisture and water-holding capacity (Table 4).

Overall, soil physicochemical properties were significantly affected by farming type and sampling locations. Conventional-farming samples exhibited substantially higher soil moisture, total N, total soluble $\mathrm{N}$, organic matter, and water-holding capacity, but lower $\mathrm{pH}$. The environmental conditions of the organic farm were relatively stable, and were not significantly affected by sampling location during the study period. 


\subsection{Microbial Community}

The microbial biomass (MB) in the soil samples collected under organic farming was significantly higher $(p<0.001)$ than under conventional farming conditions, and the microbial biomass under the canopy was higher $(p<0.001)$ than that found between the shrubs [Table 5; Fig. 3(a)]. Soil samples collected

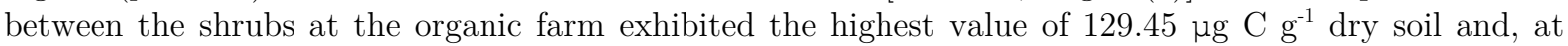
the same time, samples from under the shrubs at the conventional farm exhibited the lowest value of $65.76 \mu \mathrm{g} \mathrm{C} \mathrm{g}^{-1}$ dry soil, i.e., half the amount of the highest. (Table 2).

The metabolic quotient $\left(\mathrm{qCO}_{2}\right)$ indicates the ecophysiological state of the soil microbial community. Soil between the shrubs at the conventional farm had the highest value of $\mathrm{qCO}_{2}$, followed by the variable collected from under the canopy of the conventional farm; the values found at the organic farm were lowest (Table 2). There was no significant difference with $\mathrm{qCO}_{2}$ between two sample locations at the organic farm [Fig. 3(b)]. The metabolic quotient was found to be mainly associated with changes in total N, organic matter, and water-holding capacity (Table 4).

Basal respiration (BR) exhibited a pattern similar to that of the metabolic quotient, with the highest values of $0.93 \mu \mathrm{g} \mathrm{CO}_{2}-\mathrm{C} \mathrm{g}^{-1}$ dry soil h${ }^{-1}$ found under the canopy at the conventional farm [Fig. 3(c)]. A significant positive correlation $(\mathrm{r}=0.76, p<0.001)$ was found between basal respiration and total soluble nitrogen (Table 4).

Differences in farming type were reflected by the Shannon index $\left(H^{\prime}\right)(p<0.001$; Table 5), with significant differences between sampling locations. The mean Shannon index in soil samples between the shrubs $\left(H^{\prime}=2.57\right)$ was higher than those taken under the canopy at the organic farm, and a relatively lower value was found between the shrubs at the conventional farm $\left(\mathrm{H}^{\prime}=2.11\right)$ [Table 1; Fig. 3(d)]. The Shannon index demonstrated a correlation with total N, organic matter, water-holding capacity, and the metabolic quotient $(\mathrm{p}<0.001)$, and a positive correlation with soil $\mathrm{pH}(r=0.53, p<0.001)$ (Table 4).

\subsection{Functional Structure of the Microbial Community}

The distribution of non-metric multidimensional scaling (MDS) based on the microbial metabolic profile with fifteen carbon substrates showed two distinct groups, one for each of the two farming types (stress $=0.1$; Fig. 4 ; Table 6 ). The microbial community of conventional farming displayed a higher ability to metabolize carboxylic acids (lysine and arginine) compared with organic farming, and their substrate utilization ability was mainly expressed by the use of an amino acid (citric acid) and carbohydrates (glucose and fructose). Soil samples collected between the shrubs were distinguished from the samples collected under the canopy by a decrease in the catabolic ability of arginine and an increase in lysine and cysteine at the conventional farm. The functional profile under the canopy at the organic farm demonstrated reduced lysine, cysteine, and arginine catabolism compared with samples collected between the shrubs.

\section{Discussion and Conclusions}

Mäder et al. [17] demonstrated that organic farming improves physical and chemical soil stability compared with conventional farming. These findings are similar to our findings. All parameters measured in the present study were found to be significantly affected by farming types, and the standard errors of values at the organic farm were relatively smaller than at the conventional farm not only under the canopies but also between the shrubs (except for $\mathrm{pH}$ ). The soil microbial community was found to be sensitive to abiotic factors $[43,44]$; therefore, stable abiotic factors may be a cue of stable microbial-community structure and agroecosystem functions.

Conventional management alters the environmental conditions between the shrubs of CAII, but not beneath the shrubs of CAI, from OAI and OAII, for example: SM, TN, TSN, and OM. The application of organic nitrogen fertilizer resulted in a great increase in soil organic matter, which is consistent with previous studies $[2,45]$. However, conventional management was found to affect the $\mathrm{pH}$ value (decrease to a level of 3.21) at the CAII, indicating serious soil acidification, and nitrogen concentration in CAI and CAII may be caused by mineral fertilizers $[2,17,45]$. The considerably high $\mathrm{N}$ concentration in the CAII soil (conventional farming between shrubs) probably originated from organic nitrogen fertilizer and mineral nitrogen applications, as described by Mäder et al. [17]. These physicochemical properties very 
seldom act independently [29], and this is in line with the results of correlation analysis. Extreme acidity at the conventional farm is harmful to most microorganisms because the enzymes are mostly $\mathrm{pH}$ dependent, and will reduce the nitrification rate and modify microbial-community structure in soil if $\mathrm{pH}$ is below $6[29,46,47]$.

Functional diversity and functional group components of organisms change with the modification of environmental conditions or different management programs, and have a great impact on ecosystem processes [14, 48]. The physiological microorganism variance demonstrated an apparent farmingmanagement effect.

$\mathrm{qCO}_{2}$ reflects the maintenance requirements of the microbial biomass. As described in recent research studies, organic farming results in lower $\mathrm{qCO}_{2}$ and higher microbial biomass than conventional farming $[9,14,17,45]$. The lower $\mathrm{qCO}_{2}$ indicates that organic farming maintains the agricultural system at a lower energy budget. Consequently, microbial communities are able to use organic substances more for growth or biomass increase [17]. Furthermore, the functional diversity based on substrate-induced respiration of OAII was highest, so the mechanism of niche differentiation and coexistence may support microbial populations with extra resources [48]. Therefore, organic farming can build up a higher microbial biomass than conventional farming.

There was no significant difference in the microbial biomass between CAII and OAI, while the basal respiration of CAII was about twice as high as in other sampling locations. This pattern may be caused by an increasing dominant group of bacteria that, under high nutrient conditions, easily metabolized $\mathrm{N}$ $[28,49]$, or through the utilization of soil organic matter [50]. In addition, conventional tillage stimulates microbial activity, leading to an increase in the soil respiration rate [29].

Functional diversity was significantly different between plots, and the order was OAII > OAI > CAI > CAII. It is obvious that organic farming will increase functional diversity of a microbial community, and conversely, conventional farming has a negative impact on functional diversity, especially in plots where fertilizer is applied. Vegetation can influence the soil microbial community by root exudations [28]. Microclimate and environmental conditions at fine-scale soil ecosystems determine the general microbial community structure [13]. An increasing resource heterogeneity created by multiple root exudations from a large amount of weeds and non-tillage throughout the year at the OAII should facilitate microbial diversity. A more diverse community results in more efficient resource utilization [17].

\subsection{The Functional Structure of a Microbial Community}

The metabolic ability of samples collected from the organic farm was more outstanding and faster than at the conventional farm. OA expressed a weaker response only when lysine, arginine, and cysteine were used. In particular, the microbial community of the organic farm had a better potential for degrading recalcitrant materials such as 3,4-dihydroxybenzoic acid. This result supports earlier findings that organic farming promotes the decomposition of plant material and organic residues [14, 17], as well as enhances nutrient cycling [2]. Grayston et al. [27] indicated that a microbial community demonstrated greater utilization of multiple carbon substrates when soil was not fertilized or semi-fertilized, and this result supports our finding. This study suggests that fertilizer will decrease the metabolic function of bacterial communities [28,51], even though mineral $\mathrm{N}$ application increases the decomposition rate of organic matter by fulfilling $\mathrm{N}$ demands of microbes $[2,27,52,53]$.

Conventional-farming samples show a relatively high ability to metabolize carboxylic acids. This is in agreement with previous studies that showed that organic acids are used by a wide range of bacteria [14], and conventional farming will improve the growth of copiotrophic bacteria rather than oligotrophic microbes [54]. This result can perhaps be explained by the fact that the availability of excessive nutrients leads to a shift in the dominant microbial community of the conventional farm toward early successional species at the cost of more efficient resource users [2].

The knowledge of the relationship between biodiversity and ecosystem processes and the mechanism of how agriculture management influences the structure and function of microbial communities is still limited [26, 28]. However, this study advocates that agricultural manipulation of conventional farms, especially the application of fertilizer, has strong influences on nutrient supply, decomposition processes, and microbial-community structure. Furthermore, functional diversity was associated with $\mathrm{pH}$, soil total 
nitrogen, organic matter, and $\mathrm{qCO}_{2}$ of soil, and organic farming increases functional diversity and promotes metabolic ability and decomposition rate by modifying these physicochemical properties.

Sustainable farming is an important concept in natural farming for maintaining the health of soil, crops, the soil biotic community, and the interplay between them, leading to a long-term balance and it will be one of the most important factors determining primary productivity on a long-term scale. Such long-term balance will also help to decrease dependence on limited, non-renewable pollution resources, such as petroleum-based products, and the importation of organic materials.

\section{Acknowledgments}

The authors thank Ms. Sharon Victor for her comments and for preparing the manuscript for publication. Special thanks to the NCKU Project of Promoting Academic Excellence and Developing World Class Research Centers for the Distinguished Scholar award given to Prof. Y. Steinberger that enabled bringing this research subject to publication.

\section{References}

1. J. C. Dodd, C. L. Boddington, A. Rodriguez, C. Gonzalez-Chavez and I. Mansur, "Mycelium of Arbuscular Mycorrhizal fungi (AMF) from different genera: form, function and detection," Plant and Soil, vol. 226, no. 2, pp. 131-151, 2000.

2. K. Birkhofer, T. M. Bezemer, J. Bloem, M. Bonkowski, S. Christensen, D. Dubois, F. Ekelund, A. Fliessbach, L. Gunst, K. Hedlund, P. Mader, J. Mikola, C. Robin, H. Setala, F. Tatin-Froux, W. H. Van der Putten and S. Scheu, "Long-term organic farming fosters below and aboveground biota: Implications for soil quality, biological control and productivity," Soil Biology and Biochemistry, vol. 40, no. 9, pp. 2297-2308, 2008.

3. D. A. Wardle, K. I. Bonner, G. M. Barker, G. W. Yeates, K. S. Nicholson, R. D. Bardgett, R. N. Watson and A. Ghani, "Plant removals in perennial grassland: Vegetation dynamics, decomposers, soil biodiversity, and ecosystem properties," Ecological Monographs, vol. 69, no. 4, pp. 535-568, 1999.

4. M. A. Cavigelli and G. P. Robertson, "The functional significance of denitrifier community composition in a terrestrial ecosystem," Ecology, vol. 81, no. 5, pp. 1402-1414, 2000.

5. J. R. McLaren and R. Turkington, "Ecosystem properties determined by plant functional group identity," Journal of Ecology, vol. 98, no. 2, pp. 459-469, 2010.

6. G. A. Van der Heijden, J. N. Klironomus, M. Ursic, P. Moutoglis, R. Streitwolf-Engel, T. Boller, A. Wiemken and I. R. Sanders, "Mycorrhizal fungal diversity determines plant biodiversity, ecosystem variability and productivity," Nature, vol. 396, no. pp. 69-72, 1998.

7. B. S. Griffiths, K. Ritz, R. D. Bardgett, R. Cook, S. Christensen, F. Ekelund, S. J. Sorensen, E. Baath, J. Bloem, P. C. de Ruiter, J. Dolfing and B. Nicolardot, "Ecosystem response of pasture soil communities to fumigationinduced microbial diversity reductions: an examination of the biodiversity-ecosystem function relationship," Oikos, vol. 90, no. 2, pp. 279-294, 2000.

8. M. W. Cadotte, K. Carscadden and N. Mirotchnick, "Beyond species: Functional diversity and the maintenance of ecological processes and services," Journal of Applied Ecology, vol. 48, no. 5, pp. 1079-1087, 2011.

9. A. G. O'Donnell, M. Seasman, A. Macrae, I. Waite and J. T. Davies, "Plants and fertilisers as drivers of change in microbial community structure and function in soils," Plant and Soil, vol. 232, no. 1-2, pp. 135-145, 2001.

10. S. E. Leckie, "Methods of microbial community profiling and their application to forest soils," Forest Ecology and Management, vol. 220, no. 1-3, pp. 88-106, 2005.

11. A. C. Kennedy and K. L. Smith, "Soil microbial diversity and the sustainability of agricultural soils," Plant Soil, vol. 170 , no. pp. $75-86,1995$

12. S. J. Chapman, C. D. Campbell and R. R. E. Artz, "Assessing CLPPs using MicroReSp (TM) - A comparison with biolog and multi-SIR," Journal of Soils and Sediments, vol. 7, pp. 406-410, 2007.

13. M. M. Wander, D. S. Hendrick, D. Kaufman, S. J. Traina, B. R. Steinner, S. R. Kehrmeyer and D. C. White, "The functional significance of microbial biomass in organic and conventionally managed soils," Plant Soil, vol. 170, no. pp. 87-97, 1995.

14. P. Marschner, E. Kandeler and B. Marschner, "Structure and function of the soil microbial community in a longterm fertilizer experiment," Soil Biology and Biochemistry, vol. 35, no. 3, pp. 453-461, 2003. 
15. L. E. Drinkwater, P. Wagoner and M. Sarrantonio, "Legume-based cropping systems have reduced carbon and nitrogen losses," Nature, vol. 396, no. 6708, pp. 262-265, 1998.

16. J. P. Reganold, J. D. Glover, P. K. Andrews and H. R. Hinman, "Sustainability of three apple production systems," Nature, vol. 410, no. 6831, pp. 926-930, 2001.

17. P. Mäder, A. Fliessbach, D. Dubois, L. Gunst, P. Fried and U. Niggli, "Soil fertility and biodiversity in organic farming," Science, vol. 296, no. 5573, pp. 1694-1697, 2002.

18. J. L. Kirk, L. A. Beaudette, M. Hart, P. Moutoglis, J. N. Khironomos, H. Lee and J. T. Trevors, "Methods of studying soil microbial diversity," Journal of Microbiological Methods, vol. 58, pp. 169-188, 2004.

19. V. Torsvik, F. L. Daae, R. A. Sandaa and L. Ovreas, "Novel techniques for analysing microbial diversity in natural and perturbed environments," Journal of Biotechnology, vol. 64, no. 1, pp. 53-62, 1998.

20. P. Bridge and B. Spooner, "Soil fungi: diversity and detection," Plant and Soil, vol. 232, no. 1-2, pp. 147-154, 2001.

21. G. Muyzer, E. C. de Waal and A. G. Uitterlinden, "Profiling of complex microbial-populations by denaturing gradient gel-electrophoresis analysis of polymerase chain reaction-amplified genes-coding for 16s ribosomal-Rna," Applied and Environmental Microbiology, vol. 59, no. 3, pp. 695-700, 1993.

22. J. L. Garland and A. L. Mills, "Classification and characterization of heterotrophic microbial communities on a basis of patterns of community-level sole-carbon--source utilization," Applied and Environmental Microbiology, vol. 57, pp. 2351-2359, 1991.

23. L. Zelles, "Fatty acid patterns of phospholipids and lipopolysaccharides in the characterisation of microbial communities in soil: a review," Biology and Fertility of Soils, vol. 29, no. 2, pp. 111-129, 1999.

24. A. Frostegard and E. Baath, "The use of phospholipid fatty acid analysis to estimate bacterial and fungal biomass in soil," Biology and Fertility of Soils, vol. 22, pp. 59-65, 1996.

25. C. D. Campbell, S. J. Chapman, C. M. Cameron, M. S. Davidson and J. M. Potts, "A rapid microtiter plate method to measure carbon dioxide evolved from carbon substrate amendments so as to determine the physiological profiles of soil microbial communities by using whole soil," Applied and Environmental Microbiology, vol. 69, no. 6, pp. 3593-3599, 2003.

26. S. A. Wakelin, L. M. Macdonald, S. L. Rogers, A. L. Gregg, T. P. Bolger and J. A. Baldock, "Habitat selective factors influencing the structural composition and functional capacity of microbial communities in agricultural soils," Soil Biology and Biochemistry, vol. 40, no. 3, pp. 803-813, 2008.

27. S. J. Grayston, C. D. Campbell, R. D. Bardgett, J. L. Mawdsley, C. D. Clegg, K. Ritz, B. S. Griffiths, J. S. Rodwell, S. J. Edwards, W. J. Davies, D. J. Elston and P. Millard, "Assessing shifts in microbial community structure across a range of grasslands of differing management intensity using CLPP, PLFA and community DNA techniques," Applied Soil Ecology, vol. 25, no. 1, pp. 63-84, 2004.

28. C. B. Marshall, J. R. McLaren and R. Turkington, "Soil microbial communities resistant to changes in plant functional group composition," Soil Biology and Biochemistry, vol. 43, no. 1, pp. 78-85, 2011.

29. E. A. Paul and F. E. Clark. Soil Microbiology and Biochemistry. Academic Press; San Diego, 1989.

30. C. S. Sheh and M. K. Wang. An Atlas of Major Soils of Taiwan. NCHU Soil Survey and Testing Center; Taichung, Taiwan, 1991.

31. A. Oren and Y. Steinberger, "Catabolic profiles of soil fungal communities along a geographic climatic gradient in Israel," Soil Biology and Biochemistry, vol. 40, pp. 2578-2587, 2008.

32. D. F. Dong, Y. F. Chen, Y. Steinberger and Z. P. Cao, "Effects of different soil management practices on soil free-living nematode community structure, Eastern China," Canadian Journal of Soil Science, vol. 88, no. 1, pp. 115-127, 2008.

33. A. Oren and Y. Steinberger, "Coping with artifacts induced by $\mathrm{CaCO}_{3}-\mathrm{CO}_{2}-\mathrm{H}_{2} \mathrm{O}$ equilibria in substrate utilization profiling of calcareous soils," Soil Biology and Biochemistry, vol. 40, no. 10, pp. 2569-2577, 2008.

34. E. Ben-Dor and A. Banin, "Determination of organic-matter content in arid-zone soils using a simple loss-onignition method," Commun Soil Sci Plan, vol. 20, no. 15-16, pp. 1675-1695, 1989.

35. D. L. Sparks, A. L. Page, P. A. Helmke, R. H. Loeppert, P. N. Soltanpour, M. A. Tabatabai, C. T. Johnston and M. E. Sumner. "Methods of Soil Analysis, Part 3," in Chemical Methods. Soil Science Society of America, Inc., American Society of Agronomy, Inc., 1996

36. B. A. Schumacher. Methods for the determination of total organic carbon (TOC) in soils and sediments. Ecological Risk Assessment Support Center; 2002. 
37. K. H. Tan. Soil Sampling, Preparation, and Analysis, 2nd edition. Taylor and Francis Group; Boca Raton, FL, 2005.

38. D. R. Keeney and D. W. Nelson. "Nitrogen - inorganic forms," in Methods of Soil Analysis, Part 2, Agron Monogr 9, 2nd edition. ASA and SSSA, 1982. pp. 643-698.

39. J. P. E. Anderson and K. H. Domsch, "Physiological method for quantitative measurement of microbial biomass in soils," Soil Biology and Biochemistry, vol. 10, pp. 215-221, 1978.

40. N. Berg and Y. Steinberger, "Role of perennial plants in determining the activity of the microbial community in the Negev Desert ecosystem," Soil Biology and Biochemistry, vol. 40, no. 10, pp. 2686-2695, 2008.

41. T. H. Anderson and K. H. Domsch, "The metabolic quotient for $\mathrm{CO}_{2}\left(\mathrm{qCO}_{2}\right)$ as a specific activity parameter to assess the effects of environmental conditions, such as pH, on the microbial biomass of forest soils," Soil Biology and Biochemistry, vol. 25, no. pp. 393-395, 1993.

42. J. C. Zak, M. R. Willig, D. L. Moorhead and H. G. Wildman, "Functional diversity of microbial communities: a quantitative approach," Soil Biology and Biochemistry, vol. 26, pp. 1101-1108, 1994.

43. A. Winding, K. Hund-Rinke and M. Rutgers, "The use of microorganisms in ecological soil classification and assessment concepts," Exotoxicology and Environmental Safety, vol. 62, pp. 230-248, 2005.

44. V. Saul-Tcherkas and Y. Steinberger, "Soil microbial diversity in the vicinity of a Negev Desert shrub Reaumuria negevensis," Microbial Ecology, vol. 61, no. 1, pp. 64-81, 2011.

45. A. Fliessbach, H. R. Oberholzer, L. Gunst and P. Mader, "Soil organic matter and biological soil quality indicators after 21 years of organic and conventional farming," Agriculture Ecosystems 8 Environment, vol. 118, no. 1-4, pp. 273-284, 2007.

46. W. S. Dancer, L. A. Peterson and G. Chesters, "Ammonification and nitrification of N as influenced by soil pH and previous N treatments," Soil Science Society of America Journal, vol. 37, no. 1, pp. 67-69, 1973.

47. C. Ste-Marie and D. Pare, "Soil, pH and N availability effects on net nitrification in the forest floors of a range of boreal forest stands," Soil Biology \& Biochemistry, vol. 31, no. 11, pp. 1579-1589, 1999.

48. D. Tilman, J. Knops, D. Wedin, P. Reich, M. Ritchie and E. Siemann, "The influence of functional diversity and composition on ecosystem processes," Science, vol. 277, pp. 1300-1302, 1997.

49. H. Y. Chu, X. G. Lin, T. Fujii, S. Morimoto, K. Yagi, J. L. Hu and J. B. Zhang, "Soil microbial biomass, dehydrogenase activity, bacterial community structure in response to long-term fertilizer management," Soil Biology \& Biochemistry, vol. 39, no. 11, pp. 2971-2976, 2007.

50. F. E. Haichar, C. Marol, O. Berge, J. I. Rangel-Castro, J. I. Prosser, J. Balesdent, T. Heulin and W. Achouak, "Plant host habitat and root exudates shape soil bacterial community structure," The ISME Journal, vol. 2, pp. 1221-1230, 2008.

51. S. U. Sarathchandra, U. Ghani, G. W. Yeates, G. Burch and N. R. Cox, "Effect of nitrogen and phosphate fertilizers on microbial and nematode diversity in pasture soils," Soil Biology and Biochemistry, vol. 33, pp. 953964, 2001

52. D. S. Jenkinson, R. H. Fox and J. H. Rayner, "Interactions between fertilizer nitrogen and soil nitrogen - the socalled priming effect," Journal of Soil Science, vol. 36, no. 3, pp. 425-444, 1985.

53. A. Lagomarsino, B. A. Knapp, M. C. Moscatelli, P. De Angelis, S. Grego and H. Insam, "Structural and functional diversity of soil microbes is affected by elevated $\left[\mathrm{CO}_{2}\right]$ and $\mathrm{N}$ addition in a poplar plantation," Journal of Soils and Sediments, vol. 7, no. 6, pp. 399-405, 2007.

54. S. J. Hu, A. H. C. van Bruggen and N. J. Grunwald, "Dynamics of bacterial populations in relation to carbon availability in a residue-amended soil," Applied Soil Ecology, vol. 13, no. 1, pp. 21-30, 1999. 


\section{Appendix}

Table 1. Summary of soil physicochemical and physiological properties.

\begin{tabular}{|c|c|c|c|c|c|c|c|c|c|}
\hline Farming type & Position & $\mathrm{SM}(\%)$ & $\mathrm{pH}$ & Tot: & $-\mathrm{N}\left(\mathrm{g}^{*} \mathrm{~kg}^{-1}\right)$ & TSN & $\mathrm{ug} /$ soil g) & $\mathrm{OM}(\%)$ & $\mathrm{WHC}(\%)$ \\
\hline \multirow[t]{2}{*}{$\mathrm{CA}$} & $\mathrm{TI}$ & $24.63(0.54)$ & $4.10(0.05)$ & 0.23 & $(0.01)$ & 20.09 & $(1.80)$ & $5.64 \quad(0.21)$ & $68.75 \quad(0.62)$ \\
\hline & Tll & $51.27(0.96)$ & $3.21(0.03)$ & 0.86 & $(0.02)$ & 211.00 & $(16.60)$ & $17.13(0.33)$ & $104.31(1.05)$ \\
\hline \multirow[t]{2}{*}{$\mathrm{OA}$} & $\mathrm{TI}$ & $24.53(0.29)$ & $5.91(0.10)$ & 0.17 & $(0.00)$ & 8.19 & $(0.54)$ & $4.55 \quad(0.07)$ & $64.04 \quad(0.42)$ \\
\hline & Tll & $26.05(0.31)$ & $6.07(0.09)$ & 0.21 & $(0.00)$ & 23.00 & $(2.09)$ & $5.16 \quad(0.11)$ & $66.01 \quad(0.38)$ \\
\hline
\end{tabular}

\begin{tabular}{|c|c|c|c|c|c|c|c|}
\hline \multicolumn{4}{|c|}{ Farming type Position MB ( $\mu \mathrm{g} \mathrm{C} \mathrm{g}^{-1}$ dry soil $)$} & \multirow{2}{*}{$\frac{\mathrm{qCO}_{2}}{6.09(0.18)}$} & \multicolumn{2}{|c|}{ BR $\left(\mu \mathrm{gCO} 2-\mathrm{C} \mathrm{g}^{-1}\right.$ dry soil $\left.\mathrm{h}^{-1}\right)$} & \multirow{2}{*}{$\frac{\mathrm{H}^{\prime}}{2.34(0.03)}$} \\
\hline $\mathrm{CA}$ & $\mathrm{TI}$ & 65.76 & $(2.77)$ & & 0.40 & $(0.03)$ & \\
\hline & Tll & 101.41 & $(5.82)$ & $9.71(0.38)$ & 0.93 & $(0.06)$ & $2.11(0.05)$ \\
\hline $\mathrm{OA}$ & TI & 95.25 & $(3.76)$ & $4.64(0.21)$ & 0.41 & $(0.02)$ & $2.46(0.02)$ \\
\hline
\end{tabular}

CA, conventional farm; OA, organic farm; TI, below shrub; TII, between shrubs; SM, soil moisture; TN, total nitrogen; TSN, total soluble nitrogen; OM, organic matter; WHC, water-holding capacity; MB, microbial biomass; $\mathrm{BR}$, basal respiration; $\mathrm{qCO}_{2}$, metabolic quotient; $\mathrm{H}^{\prime}$, microbial functional diversity; the number in parenthesis are standard deviation.

Table 2 The different carbon substrates added to soil in MicroResp ${ }^{\mathrm{TM}}$ divided into chemical groups.

\begin{tabular}{llll}
\hline Carboxylic acids & Carbohydrates & Aromatic carboxylic acids & Amino acids \\
L-Alanine & L-Arabinose & 3,4-Dihydroxybenzoic acid & Citric acid \\
Arginine & D-Fructose & (protocatechuic acid) & L-Malic acid \\
L-Cysteine HCl & D-Galactose & & Oxalic acid \\
Gamma-Amino butyric acid & D-Glucose & & \\
L-Lysine & Trehalose & & \\
N-Acetyl-Glucosamine & & & \\
\hline
\end{tabular}

Table 3. Summary of ANOVAs for soil physicochemical properties over the entire study period; test for farming type and position treatment.

\begin{tabular}{cccccccc}
\hline \multirow{2}{*}{ Soil property } & \multicolumn{2}{c}{ Farming type effect } & \multicolumn{3}{c}{ Position effect } & \multicolumn{2}{c}{ Farming type $\times$ Treatment } \\
\cline { 2 - 3 } & $\mathrm{F}_{\text {value }}$ & $\mathrm{P}$ & $\mathrm{F}_{\text {value }}$ & $\mathrm{P}$ & $\mathrm{F}_{\text {value }}$ & $\mathrm{P}$ \\
\hline $\mathrm{SM}$ & 457.13 & 0.000 & 565.14 & 0.000 & 449.63 & 0.000 \\
$\mathrm{pH}$ & 1100.57 & 0.000 & 27.24 & 0.000 & 56.77 & 0.000 \\
$\mathrm{TN}$ & 1415.79 & 0.000 & 1265.75 & 0.000 & 964.45 & 0.000 \\
$\mathrm{TSN}$ & 140.43 & 0.000 & 148.73 & 0.000 & 108.99 & 0.000 \\
$\mathrm{OM}$ & 1013.69 & 0.000 & 870.26 & 0.000 & 702.78 & 0.000 \\
$\mathrm{WHC}$ & 1015.09 & 0.000 & 772.83 & 0.000 & 619.27 & 0.000 \\
\hline
\end{tabular}


Table 4. Pearson's correlation coefficients between the variables. Correlation coefficient between different variances for soil samples representing the different treatments.

\begin{tabular}{cccccccccc}
\hline & $\mathrm{SM}$ & $\mathrm{pH}$ & $\mathrm{TN}$ & $\mathrm{TSN}$ & $\mathrm{OM}$ & $\mathrm{WHC}$ & $\mathrm{MB}$ & $\mathrm{BR}$ & $\mathrm{qCO}_{2}$ \\
\hline $\mathrm{pH}$ & $0.66^{* * *}$ & \multicolumn{10}{c}{$\mathrm{CO}^{* * *}$} & & & & & \\
$\mathrm{TN}$ & $0.96^{* * *}$ & $0.72^{* * *}$ & & & & & \\
$\mathrm{TSN}$ & $0.70^{* * *}$ & $0.60^{* * *}$ & $0.77^{* * *}$ & & & & & \\
$\mathrm{OM}$ & $0.96^{* * *}$ & $0.71^{* * *}$ & $0.99^{* * *}$ & $0.76^{* * *}$ & & & & & \\
$\mathrm{WHC}$ & $0.93^{* * *}$ & $0.74^{* * *}$ & $0.96^{* * *}$ & $0.72^{* * *}$ & $0.96^{* * *}$ & & & & \\
$\mathrm{MB}$ & $\mathrm{NS}$ & $0.25^{* * *}$ & $\mathrm{NS}$ & $0.24^{* * *}$ & $\mathrm{NS}$ & $\mathrm{NS}$ & & & \\
$\mathrm{BR}$ & $0.54^{* * *}$ & $0.41^{* * *}$ & $0.59^{* * *}$ & $0.76^{* * *}$ & $0.60^{* * *}$ & $0.58^{* * *}$ & $0.55^{* * *}$ & & \\
$\mathrm{qCO}_{2}$ & $0.64^{* * *}$ & $0.69^{* * *}$ & $0.71^{* * *}$ & $0.68^{* * *}$ & $0.72^{* * *}$ & $0.76^{* * *}$ & $0.17^{*}$ & $0.66^{* * *}$ & \\
$\mathrm{H}^{\prime}$ & $0.49^{* * *}$ & $0.53^{* * *}$ & $0.54^{* * *}$ & $0.43^{* * *}$ & $0.55^{* * *}$ & $0.56^{* * *}$ & $0.20^{* *}$ & $0.38^{* * *}$ & $0.63^{* * *}$ \\
\hline
\end{tabular}

$\mathrm{SM}$ - soil moisture, pH, TN - total nitrogen; TSN - total soluble nitrogen; OM - organic matter WHC - waterholding capacity, $\mathrm{MB}$ - microbial biomass ; qCO2 - metabolic quotient. p values:

${ }^{*} \mathrm{p}<0.05 ;{ }^{*} \mathrm{p}<0.01 ; * * * \mathrm{p}<0.0001$

Table 5. Summary of ANOVAs for physiological variances during the entire study period; test for farming type and position treatment (NS -non significant).

\begin{tabular}{|c|c|c|c|c|c|c|}
\hline \multirow{2}{*}{ Soil property } & \multicolumn{2}{|c|}{ Farming type effect } & \multicolumn{2}{|c|}{$\underline{\text { Position effect }}$} & \multicolumn{2}{|c|}{ Farming type $\times$ Treatment } \\
\hline & $\mathrm{F}_{1,236}$ & $\mathrm{P}$ & $\mathrm{F}_{1.236}$ & $\mathrm{P}$ & $\mathrm{F}_{1.236}$ & $\mathrm{P}$ \\
\hline $\mathrm{MB}$ & 32.47 & 0.00001 & 47.89 & 0.00001 & 0.02 & NS \\
\hline $\mathrm{qCO}_{2}$ & 201.29 & 0.00001 & 40.59 & 0.00001 & 69.31 & 0.00001 \\
\hline $\mathrm{BR}$ & 32.91 & 0.00001 & 71.94 & 0.00001 & 37.25 & 0.00001 \\
\hline $\mathrm{H}^{\prime}$ & 89.30 & 0.00001 & 3.36 & NS & 31.00 & 0.00001 \\
\hline
\end{tabular}

Table 6. The strongest variables (substrates) associated with the differences based on the catabolic profile of a microbial community under conventional farming and organic farming.

\begin{tabular}{ccccc}
\hline Substrate & \multicolumn{1}{c}{ Type of substrate Average value of CA Average value of OA Contribution \% } \\
\hline L-Lysine & Carboxylic acid & 1.42 & 0.46 & 11.58 \\
Arginine & Carboxylic acid & 1.07 & 0.31 & 10.29 \\
Citric acid & Amino acid & 0.29 & 0.91 & 8.81 \\
D-Glucose & Carbohydrate & 0.34 & 0.91 & 8.09 \\
D-Fructose & Carbohydrate & 0.29 & 0.80 & 8.08 \\
\hline
\end{tabular}

$\mathrm{CA}$, conventional farm; OA, organic farm

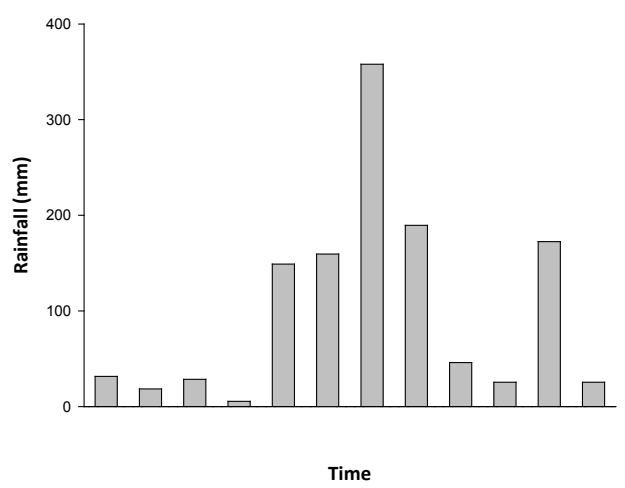

Figure 1. Monthly rainfall in the research area throughout the study period (Jan-Dec 2011). 
(a)

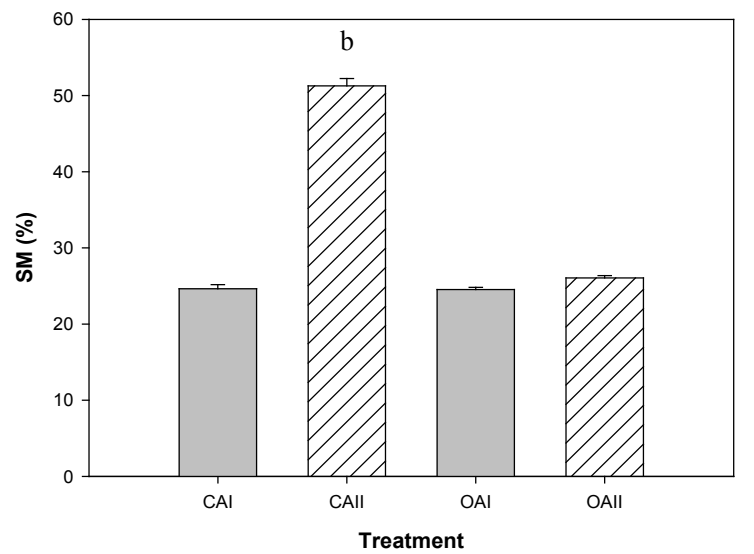

(c)

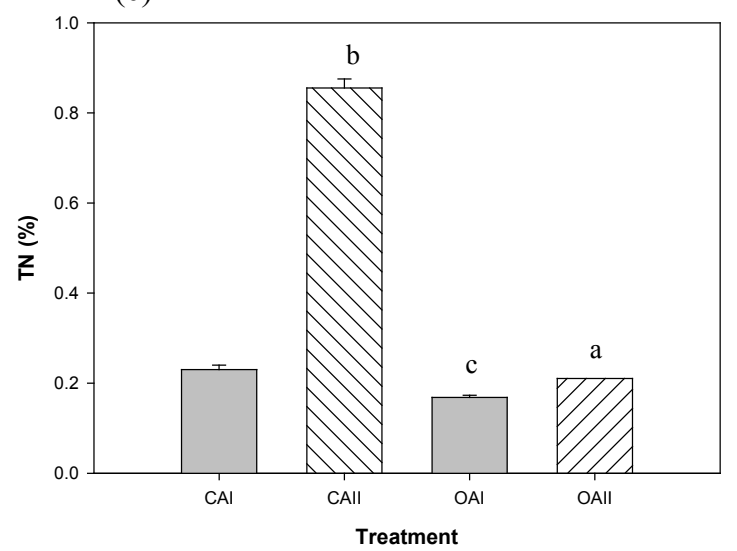

(e)

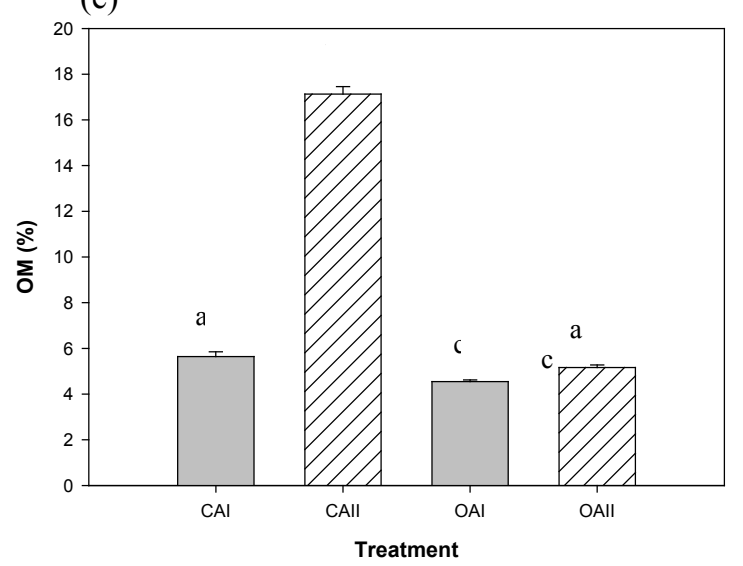

(b)

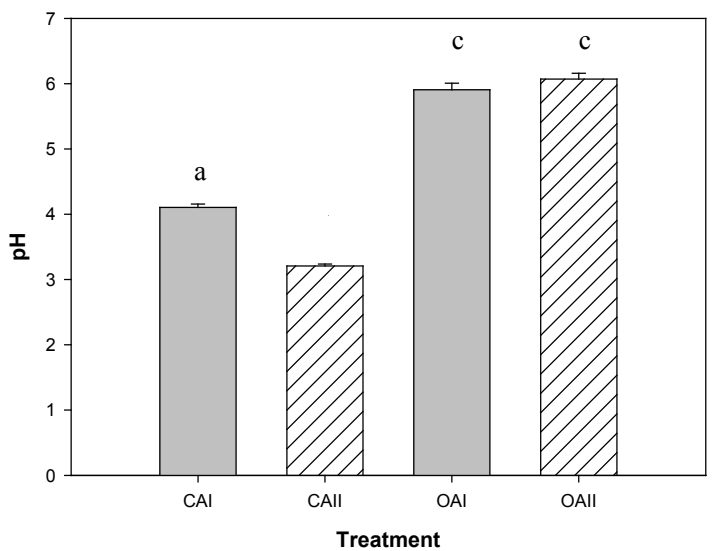

(d)

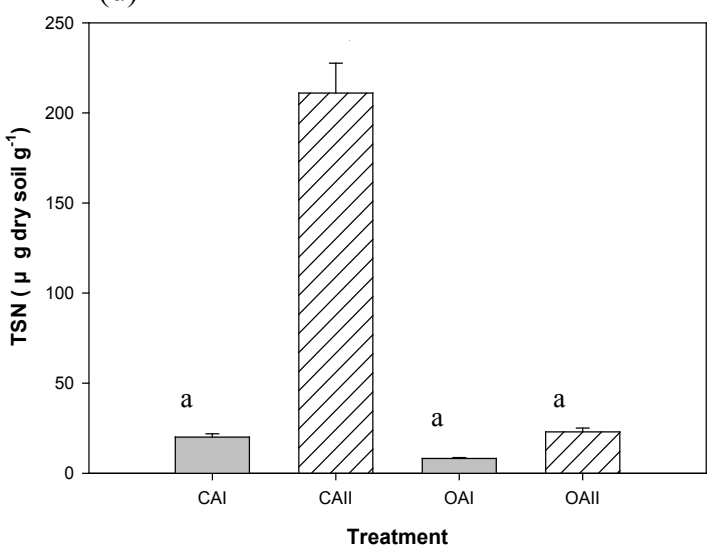

(f)

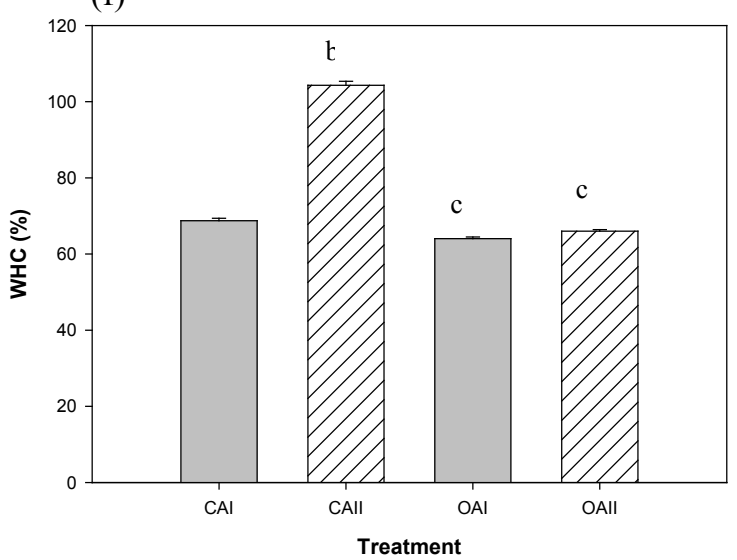

Figure 2. Mean physicochemical properties $( \pm \mathrm{SE})$ in different treatments. Bars with the same letter are not significantly different, using Tukey's comparison of all means. (CA, conventional farm; OA, organic farm; I, below shrub). 
( a)

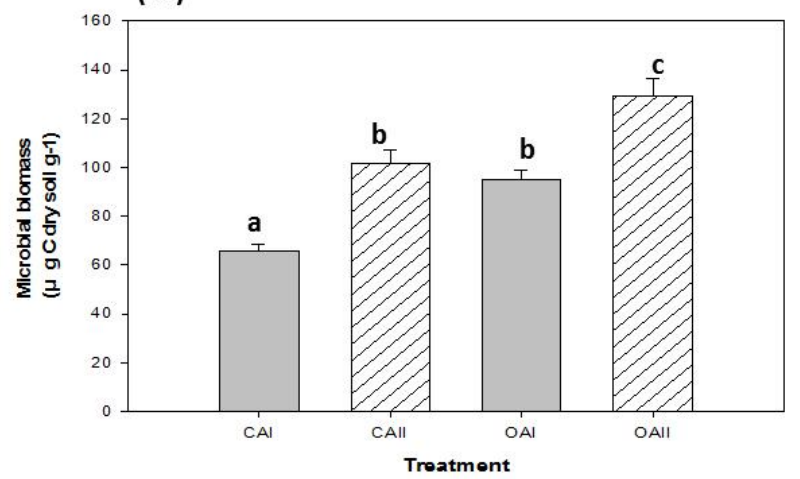

(c)

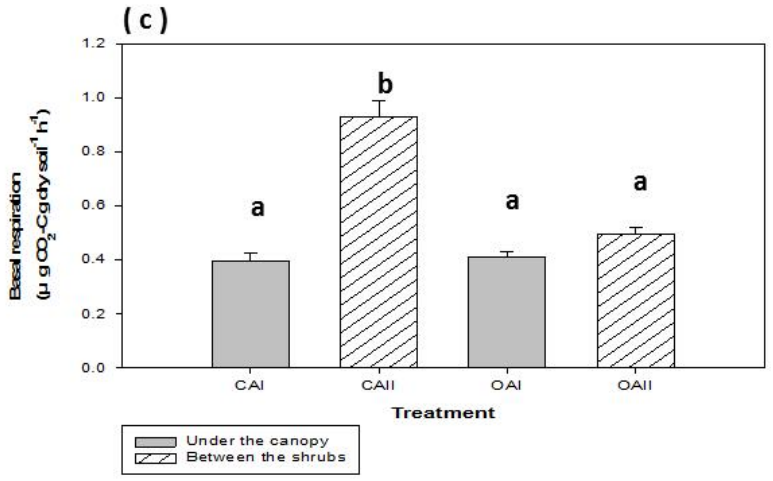

(b)
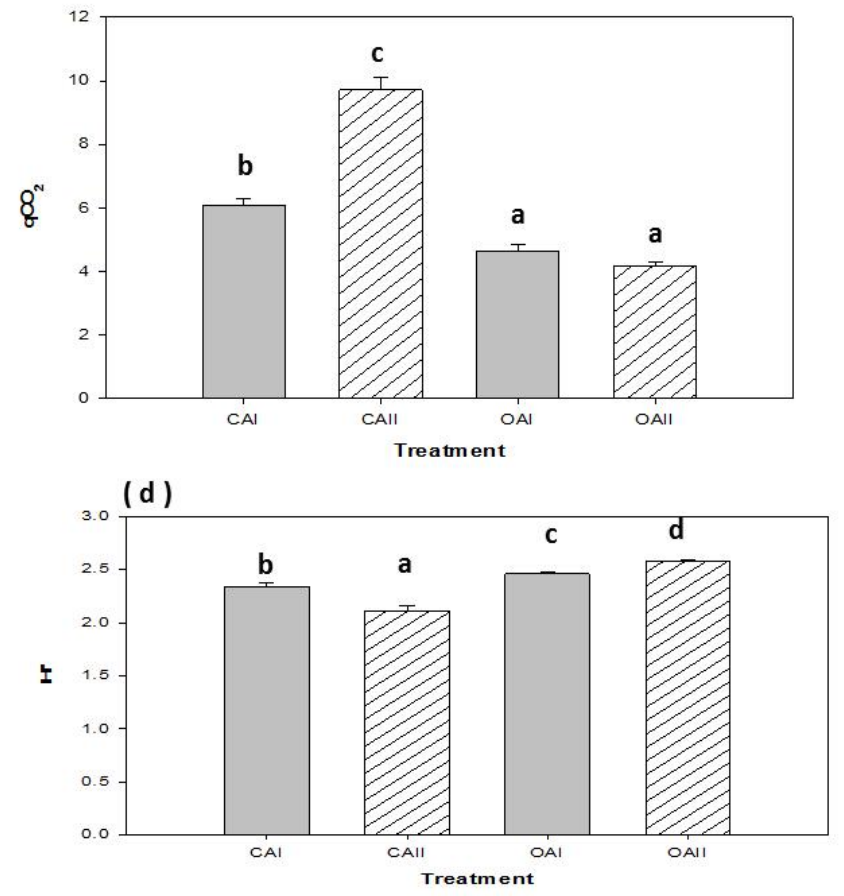

Figure 3. Mean physiological variables $( \pm \mathrm{SE})$ in different treatments. Bars with the same letter are not significantly different, using Tukey's comparison of all means. (CA, conventional farm; OA, organic farm; I, below shrub; II, between shrubs).

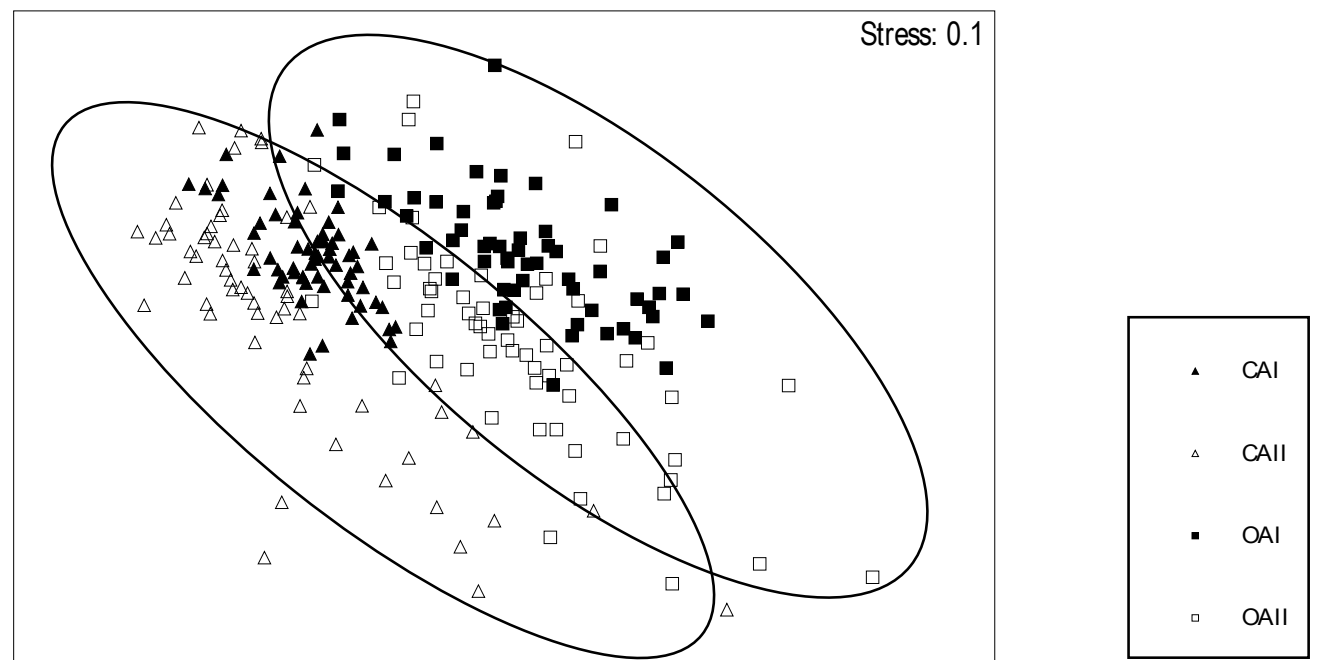

Figure 4. The non-metric multidimensional scaling (MDS) plot based on normalized Euclidean distances generated from catabolic-utilization $\left(\mathrm{CO}_{2}\right.$ evolution) data. (CA, conventional farm; OA, organic farm; I, below shrub; II, between shrubs). 